\title{
リモートセンシングに立脚した沿岸海域自走渦の運動論的研究

\author{
KINEMATIC STUDY OF SELF-PROPELLED MARINE VORTICES \\ BASED ON REMOTELY SENSED DATA
}

\author{
西村 司*·畠 山祐二**・田中総太郎*** · 丸 安 隆 和**** \\ By Tsukasa NISHIMURA, Yü̈ HATAKEYAMA, Sotaro TANAKA and Takakazu MARUYASU
}

\begin{abstract}
Based on remotely sensed data from space and air, some isolated marine vortices have been found to be propelling temselves along the coastline at the Suruga Bay and at the Akashi Strait, which are generated respectively by the shear of the Kuroshio or the tidal current. A kinematic discussion has been developed about the characteristics of these self-propelled marine vortices, and following results are obtained. These self-propelled vortices accompanied by a substantial mass transport and by a coastal current have an important role in the coastal current system. The earth rotation effects support the action of the counterclockwise marine vortices which are generated at the Pacific Coast of Japan by the shear of the Kuroshio.
\end{abstract}

\section{1.はじめに}

わが国を取り巻く沿岸海域は, 2 種類の高速の流れを もつ. 太平洋岸を洗う黒潮と瀬戸内海の各海峡を往復す る潮流である. 最近著しく進歩を遂げたリモートセンシ ング技術が，これらの高速の流れと陸岸との間のシアー によって生ずる孤立した渦の存在とその決定論的な運動 との記録を可能とした. 今まで誰もが目で確認すること のできなかった現象である.

1976 年, 著者らの研究グループは大鳴門橋の建設に 関連して,鳴門の渦潮の研究を実施する機会に恵まれた。 鳴門海峡の潮流は周知のように 10 ノット以上に達する 激しい流れであり，海峡最狭部の両側から突出する陸岸 との間のシアーによって生ずる雄大な渦は多くの人々の 興味を誘ってきた．われわれはこの渦の生成, 発達およ びその沿岸海域流動に果たしている役割のメカニズム研 究に初めてリモートセンシング技術を導入し，それに

\footnotetext{
* 正会員 工博 東京理科大学助教授 理工学部 ( ₹ 278 野田市山崎 2641)

**正会員 理修 アジア航測（株）立地環境部 ( テ 243 神奈川県厚木市船子 568)

*** 正会員 工博 リモートセンシング技術センター ( 106 港区六本木 7-15-17)

***** 正会員 工博 東京理科大学教授 理工学部 (厂 278 野田市山崎 2641)
}

よって多くの成果を挙げることができた 立した渦の運動論は解析の道具として大きい役割を果た した.

これ以来，われわれは沿岸海域の多くの衛星デー夕を 常に注意深く観察しており，それによって海峡水域と同 様に黒潮と海岸線との間の海域にもシアーに基づく多く の孤立した洞が存在することを見出した．特に興味をひ いたのは, これらの渦が海岸線に沿ってかなりの速度で 自走するということであった. 本研究はこれらの渦を自 走渦と名付け, リモートセンシングデータに立脚してそ の運動のメカニズムおよび沿岸海域環境における役割を 評価することを試みるものである.

海洋におけるスケールの大きい孤立した渦の研究は, 1970 年代に入り，メキシコ湾流に伴う「リング」の研 究を契機として主として外洋の中規模渦を対象として進 められている(たとえば Robinson ${ }^{2)}$ )。これに対し本研 究は沖合を流れる主流と海岸線との間のシアーに基づく 沿岸海域の渦を対象とする.この種の渦の運動とその沿 岸海域流動における役割とを対象とするメカニズム研究 は, 出入りの激しい海岸地形と高速の流れとの双方をあ わせもつわが国においては沿岸海域の流動環境を把握す るうえできわめて実際的な意義をもつものと思われる. 


\section{2. 研究の進め方}

本研究は, 従来主として陸上の静止した事物を対象と して発達してきたりモートセンシング技術を海域に実在 する非定常な運動状態の解明に適用しようとする．した がって，研究手法もまたおのずと従来とは異なったもの となり，本研究においては以下のような手順を踏んでい る.まず，リモートセンシングデータをもとに渦の現象 の発生からこれに続く運動およびこれに誘発される沿岸 海域への影響のメカニズムについて理論的意味付けを行 う. 次に，その考察の正当性を確かめるために沿岸海域 においてすでに知られている現象亡照合し，その普遍性 の検証のために実験室におけるモデル実験を加える．以 上の手順は，おのおのリモートセンシングを陸上に適用 する際の判読およびグランドトルースに相当するもので あり，特に，その場所に近づいて実測することの困難な 海洋流動のリモートセンシングに特有の方法であると考 えられる。

理論的意味付けにあたっては Lamb ${ }^{3}$ にみられる古典 的な「孤立した渦の運動論」を沿岸海域固有の条件に合 わせて使用し,力学的議論には立ち入らないこととした. これは，1つには最近発達しつつあるコヒーレント構造 の研究手法を適用してゆくことを念頭に置いたためであ り，あと1つには現時点における現地観測技術が渦の力 学的議論を十分にサポートするまでには発達していない ことを考虑したことによる.

最も簡単な渦の自走のメカニズムは渦の運動論によっ て以下のように表現されている．すなわち，Fig.1 (a) のように互いに逆回転する同じ強さの 2 つの渦が渦対を なしているものとすれば，この渦対は一様速度

(a)

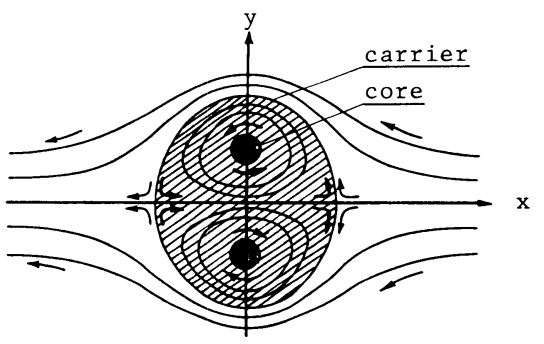

(b)

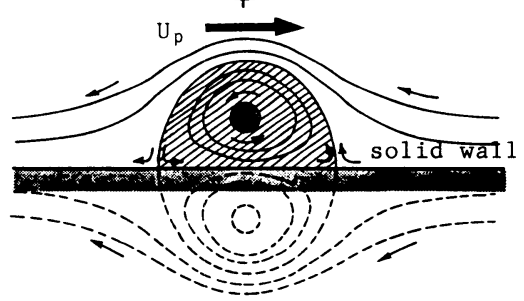

Fig. 1 Self-propelled motion of vortices. ((a) vortex-pair, (b) image effect)

$$
U_{p}=\frac{\Gamma}{4 \pi a}
$$

をもって図の向きに自走する.ここに $\Gamma$ は渦の強さ， 2 $a$ は渦軸間の距離である. 図はまたこの渦対と行動を共 にする座標系からみた定常流線網を示す。一方，図 (b) のように単独の渦が剛体壁近傍に位置したとすればこの 渦もまた式（1）の速度をもって自走する．ここに $a$ は渦軸と壁面との間の距離である，以下，用体壁の渦に 及ぼすこのような運動論的な影響を「イメージ効果」と 称するが，これは，渦があたかも剛体壁背部にイメージ としての逆回転の渦があるかのような運動を呈している ことによる.ここに注目すべきはこれらの自走渦が図中 斜線部のキャリヤ内部の実質流体の輸送を伴うというこ とである.

自然界におけるスケールの大きい渦の自走の運動論的 研究例は, Barker $~^{4)}$ の航空機翼端渦の研究にみるこ之 ができる，航空機が離陸もしくは着陸するとき，滑走路 上空には翼の両端から左旋・右旋の一対の渦が延びる.

このとき，渦はまず渦対の自走機構によって地上に舞い 降りた後, 地表面からイメージ効果を受けて左右へと分 離する．Barker らは地表面の近傍の渦に及ぼすこの影 響を「ground effect」と名付け，これらの渦を無限に延 びる平行な直線状の渦とみなしてその運動を渦運動論に よって解析し，有界な水槽を用いた室内モデル実験に よって検証している。

以上の渦に対し，本研究で取り扱う自走渦は $2 つ$ 特 色をもつ. 1 つは, 渦の長さが極端に限られており，そ のアスペクト比（渦の長さ/直径）が 1 あるいは 0.1 の

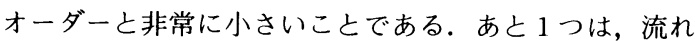
の場が自由水面, 海底面あるいは海岸線によって限られ た有界なものであるということである。したがって，理 論的意味付けにあたっては主に無限の流れの場として記 述されている渦の運動論をこの特殊な渦の運動へと適用 するために種々の仮定を設けている．このアプローチの 適用性は室内モデル実験によって検証される．また，地 球自転の影響は実験的に考慮に入れられる.

\section{3. リモートセンシングデータからの自走洞の 検出}

\section{（1）黒潮によって形成される自走渦}

わが国沿岸海域における代表的な高速の流れとして は，「黒潮」を挙げることができる，黒潮と太平洋岸と の間のシアーによって形成される自走渦の存在は, 畠山 $ら^{5)}$ の 1979 年 10 月 20 日から 23 日にかける Landsat データおよび一連の NOAA データを用いた観測によっ て, 駿河湾において見出された。Fig. 2 に代表的な 2 葉 の NOAA 画像を示す．画像（a）は10月 20 日 18 時 26 
分の状海であり，駿河湾口における左旋の渦の形成亡周 囲水の渦内部八の巻込みの状況が示されている。一方, 画像 (b) は10月 23 日 7 時 44 分の状況であり，渦が 伊豆半島西岸沿いに北上している状況をみることができ る. Fig. 3 はこれらの画像解析によって得られた渦の振 舞いを時系列としてまとめたものであり, おのおの, (A) 湾口部における左旋の渦の形成と周囲水の巻込み, (B) その形成終了，(C) 伊豆半島への接近および (D) 伊 豆半島西岸沿いの北上の様子を示している.

本海域の海底地形の特徵はFig. 4 に示すように, 両側 に2つの顕著な浅瀬を有する深い湾であることにある. すなわち, 御前崎沖 $30 \mathrm{~km}$ にわたって延びる浅瀬の先 端には水深 $50 \mathrm{~m} の 「$ 金洲の瀬」が笑出し, 伊豆半島沖 合いには水深 $200 \mathrm{~m}$ 程度の浅瀬が延びている.

このような海底地形条件および観測当時の黒潮主流が 駿河湾口にきわめて接近していたという流動条件を考慮 すると, Fig. 3 の左旋の渦の振舞は以下のように説明で

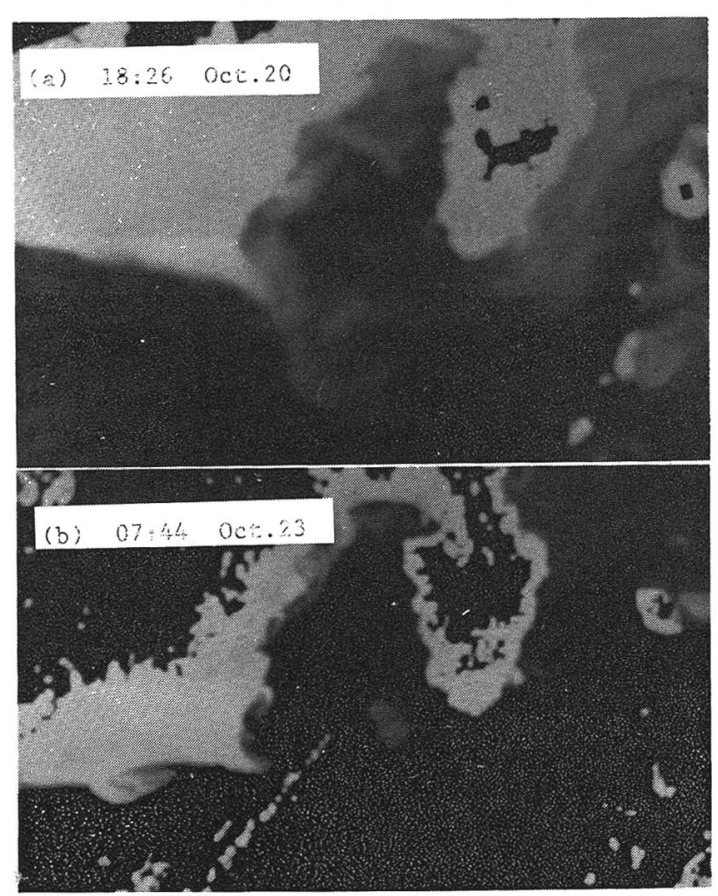

Fig. 2 NOAA imageries; by Hatakeyama ${ }^{5)}$.
きる.すなわち，(A) は接近した黒潮が金洲の瀬より シアーを受けて左旋の渦を形成している状態, (B), (C), (D) はこの左旋の渦が伊豆半島およびその延長 の浅瀬からのイメージ効果を受けて北上し, 湾内へと呑 み込まれる運動を示している.この渦の自走速度は約 1 ノット，その容量は $10^{11} \mathrm{~m}^{3}$ のオーダーに及ぶ可能性が ある。

中村ら ${ }^{61}$ は本海域における毎日の水温分布測定をとお して各種水塊の移動を把握する研究を進めており，駿河 湾内に 3〜4 日スケールの大規模な短期変動が存在する ことを示している. Fig. 5 は，中村らによって得られた 1979 年 10 月 23 日の水温分布図である. $23^{\circ} \mathrm{C}$ の等水温 線が湾口より伊豆半島西岸へと带状に延びるとともに湾 内に閉曲線をなすが，前日および翌日の観測はこのよう

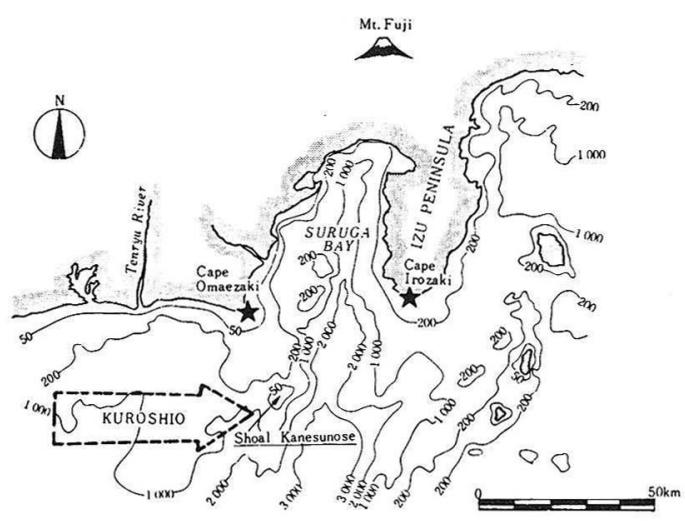

Fig. 4 Depth chart of the Suruga Bay.

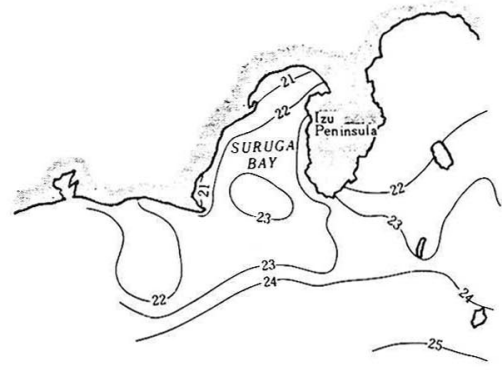

Fig. 5 Temperature chart; by Nakamura ${ }^{6)}$.

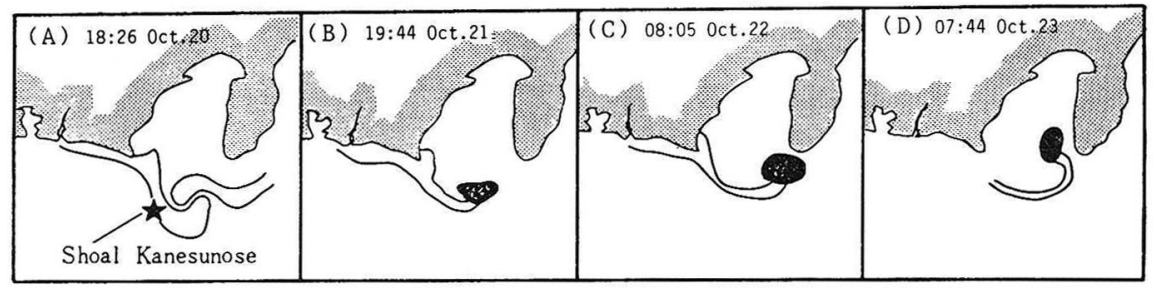

Fig. 3 Time series of the self-propelled motion of the isolated vortex.; by Hatakeyama ${ }^{5)}$. 
な分布を示していない，これらは，先の NOAA 画像に よって得られた自走渦の挙動によく対応している.

もし，このような渦の自走機構か確かに存在するもの とすれば，駿河湾内の海水の多くの部分が，金洲の瀬背 部における左旋の渦の発生後数日の内に黒潮系統の外洋 水に置き換わることとなる．すなわち，自走渦の実質水 塊輸送能力は中村らのいう3〜4 日スケールの短期変動 および湾内水の更新プロセスに寄与する可能性がある.

いま，黒潮流路とわが国の太平洋岸海底地形との双方 を概観すると，同様の左旋の渦が豊後水道，土佐湾，紀 伊水道，熊野灘そして鹿島灘において期待できる．これ らの渦のみなもととなるシアーの生成点, すなわちそれ らの海域の上流に位置する海岸地形突出点はおのおの, 種子島, 足摺岬, 室戸岬, 潮岬そして野島崎となる. 事実, NOAA データの蓄積は,これらの海域における左旋の 渦の存在とその種々の様相とを明らかにしつつある。例として, Fig. 6 に杉村ら”によって解析された NOAA データを示す. 1983 年 4 月 25 日 03 時 14 分に得られた データであり，足㨨岬，室戸岬および潮岬に左旋の渦の 形成の様子をみることができる. 田中ら ${ }^{81}$ は黒潮周辺の 孤立した渦の運動の追跡に十分な精度をもつNOAA デー夕の幾何補正の手法を開発した。これによって，黒 潮の流動変動に対する渦運動論的研究が可能となってい る $\left(\right.$ 杉村ら $\left.{ }^{91}\right)$.

\section{（2）海峡水域の潮流によって形成される自走渦}

わが国沿岸海域におけるあと 1 つの高速の流れとして 瀬戸内海の多くの海峡を通過する潮流を挙げることがで きる．鳴門海峡におけるリモートセンシングの展開"は， 通常の数十 $\mathrm{m}$ スケールの鳴門の渦の外にそれらが集積 してできる数 $\mathrm{km}$ スケールの渦対が形成されること，お よび，その渦対の Fig. 1 (a) の機構に基づく自走運動 が海峡を通しての実質水塊輸送を伴い，内外水域の海水 交換に大きい役割を果たしていることを示した。

一方，イメージ効果を受けて海峡水域の海岸線に沿っ て自走する渦の存在を明石海峡においてみることができ る. Fig. 7 は, 1972 年 10 月 24 日 10 時 06 分に得られた 当海域の Landsat 画像である. 潮汐表 ${ }^{101}$ に上れば当日の 海峡中央部流速は

$$
\begin{aligned}
& 5: 23- \\
& 8: 42 \text { 東流より西流へ転流 } \\
& 12: 09-\text { 西流最強時 } 6.4 \text { 一ット } \\
& \text { 西流より東流へ転流 }
\end{aligned}
$$

であった。すなわち，この画像は西流へ転流後 4 時間 40 分経過後の状況を示していることとなる．画像上に は西流によって淡路島東岸に沿って発達した境界層が淡 路島北端より永離して左旋の渦を形成している様子が観 察される．この渦は西向きの潮流によって流されること なく淡路島北端背部水域にとどまったまま成長し，この

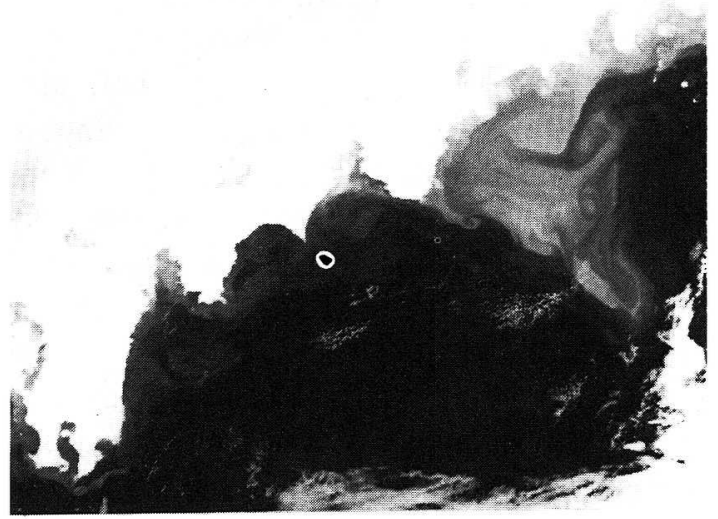

Fig. 6 NOAA imagery at $03: 14$ Apr. 25 1983, ; by Sugimura ${ }^{7)}$.

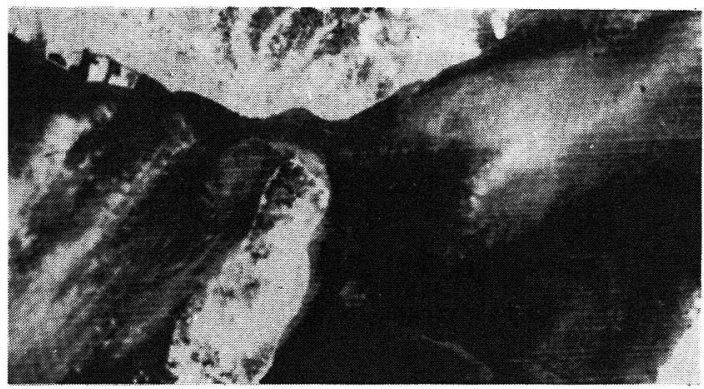

Fig. 7 Landsat imagery at 10:06 Oct. 241972.

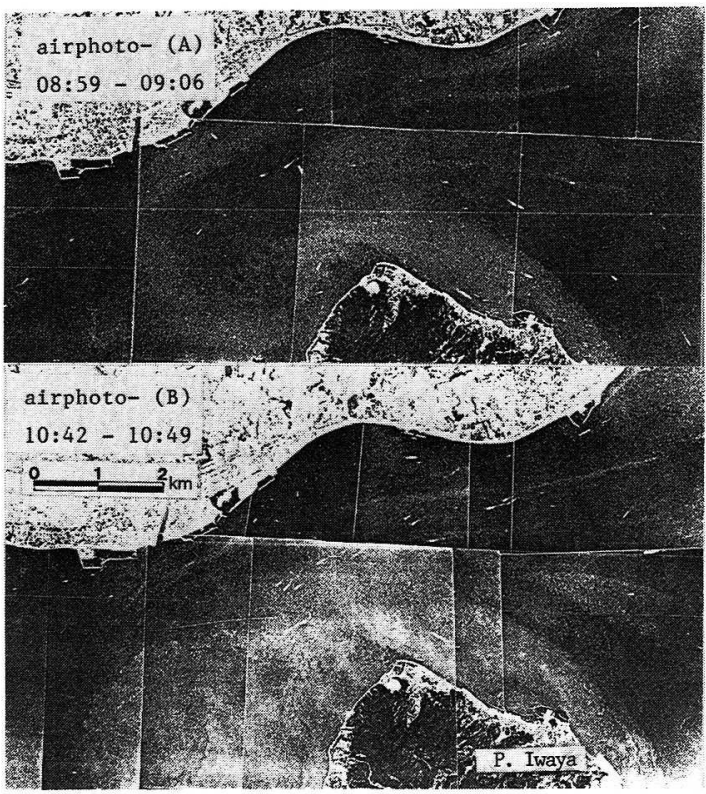

Fig. 8 Airphotos on Oct. 26 1976.; from the reference(10)

画像の得られた時点ではその直径はすでに海峡幅のス ケールに達している.

この左旋の渦の成長過程の時系列的情報は 1976 年 10 
月 26 日本四公団によって撮影された一連の航空写真 ${ }^{11}$ によって得られる. Fig. 8 はその一例を示すものであり， おのおの左旋の渦が海面に散布したトレーサによって可 視化されている. 航空写真 (A) は 8 時 59 分, (B) は その 2 時間後 10 時 42 分に撮影されたものである.

Fig. 9 はこれらの航空写真より判読した流れの様子と 潮汐表によって得た当日の海峡中央部の潮流流速とを比 較したものである. 流れの場は, 海峡中央部の主流, 明 石海岸線に沿う壁面境界層および淡路島沿岸の境界層の 3 つの領域に分けることができる. 淡路島沿岸の境界層 は岩屋港付近より㔀離して自由境界層および左旋の渦を 形成する. 航空写真 (A) はこの左旋の渦の形成過程の 初期の段階にあり, (B) はその中盤の状況を示している. (B) の時点においては渦の直径はすでに海峡幅のスケー ルに達している.

この左旋の渦が西流によって流されることなく淡路島 北端背部水域にとどまったまま生長することは, 淡路島 海岸線の左旋の渦に及ぼす海峡中央部に向けてのイメ一 ジ効果を考慮することによって説明できる．この考察の 正当性を裏付けるために, 以下に 2 種類の既存の観測資 料を検討する.

まず, 藤原 ${ }^{12)}$ は, Landsat 画像および航空写真の解析 によって,この左旋の渦が Fig. 10 に示すような挙動を 示すことを見出し，その運動を以下のように記述してい る.

すなわち,「(a) 西流時に淡路島北端に形成された反 流渦は, (b) 転流時には東向きの流れの先頭を切って 大阪湾へと流入し，(c) 東流時には播磨灘より大阪湾へ と流入した滬滴状の水塊の外縁に沿って帯状に分布す る.」と.このような左旋の渦の興味深い振舞のメカ二ズ ムは, それに及ぼす淡路島西岸のイメージ効果を考虑す ることによって説明することができる．すなわち，渦は 海峡最狭部に向かって自走するために，西流時には淡路 島西岸水域にとよ゙まったまま発達しつつ転流を待ち, 転 流時には東流に先んじて海峡を通過するのである.

一方, 潮汐表 ${ }^{10)}$ には明石海峡の潮流状況に関して以下

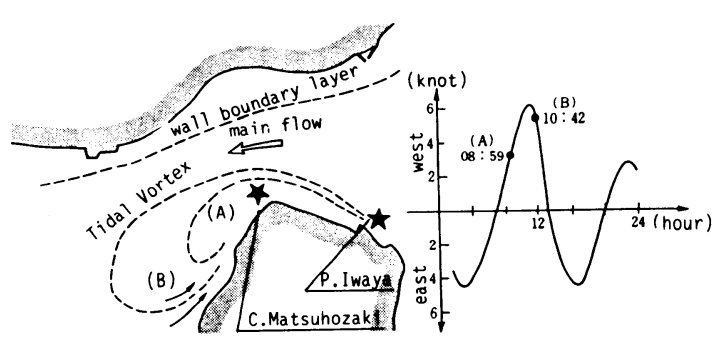

(a) flow field

(b) tidal phase

Fig. 9 Growth of the tidal vortex.

の記述がみられる、すなわち、「主流は海峡の中心線上 で海峡の幅の約 3 分の 1 の幅の区域である.この線の北 側は北に向かうに従って次第に流速を減じ，中央主流と 潮時の差は少ないが，主流の南側は激潮を生ずる所があ り，松帆埼付近は比較的流速が大きく，潮時は中央主流 より 20－50 分早い.」と.これらの記述は Fig. 9 に示す 海峡北側水域における壁面境界層の存在, 淡路島側水域 における境界層の剝離と左旋の渦の形成，それによる主 流幅の減少および転流に先だっての左旋の渦の海峡通過 というようなりモートセンシングによって初めて得られ る情報をもとに統一的に説明できるのである.

\section{4. 自走機構の運動学的解析}

リモートセンシングによって把握された自走渦は瀬戸 内海の海峡水域あるいは太平洋岸のいくつかの岬の近傍 の海況に大きい影響をもつことが予測された。しかしな がら,リモートセンシングデータのみによってはこれら の渦によってもたらされる諸現象を解明することは困難 である、そこで, fluid mechanics 的な解析を加えるこ とによってリモートセンシングデータのもつ意味とその もたらす効果とに普遍性を与える必要がある.ここでは, 特にイメージ効果によって自走する渦を対象として古典 的な渦運動論に立脚した解析を行う.

\section{（1）渦運動論の適用}

潮流や黒潮などの高速の流れに直面する海岸線におい ては, 海底は一般に沖合へと急に落ち込む地形を有して

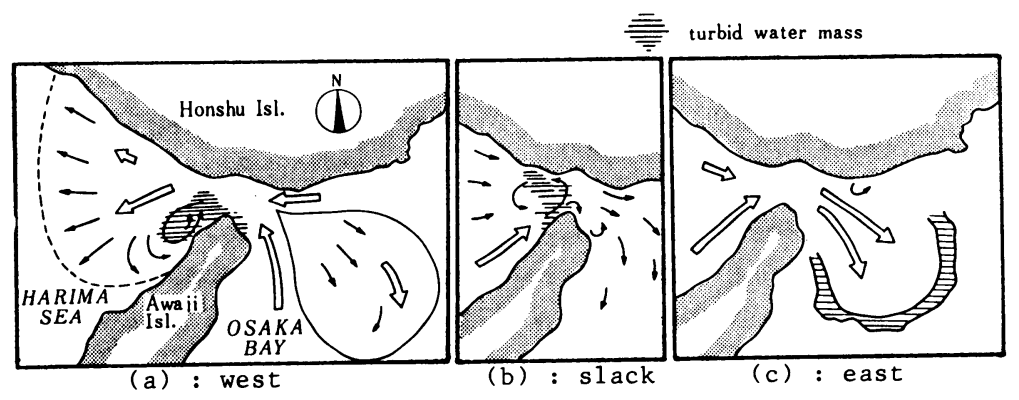

Fig. 10 Motion of the counterclockwise tidal vortex; from Fujiwara ${ }^{12)}$. 
いる. そこで，第一次の近似モデルとして Fig.11 (b) のように水平な海底面および鈶直な海岸線を想定する. この仮定のもとで渦の自走機構を表現する「渦対モデル」 が以下のようにして得られる.

一般に渦による水粒子の回転面は渦軸に垂直であるか ら,この地形条件のもとで海岸線近傍の渦を海面と海底 とに直交する鉛直回転軸と仮定する．境界を剛体壁とみ

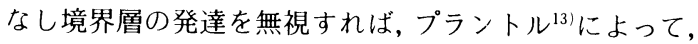
この流れは図（a）に示寸無限に続く完全流体中の渦対 の場を,それを横切る流体運動のないような 3 つの平 面 $\alpha, \beta, \gamma$ によって切り出したものと同等になること が示される. したがって, 無限空間の渦対についてのポ テンシャル理論の記述は, そのまま值接に沿岸海域の有 界な自走渦のメカニズムの説明に適用できることにな る.

こうして得られる自走渦のまわりの定常流線網を Fig 12 に示す。これは自走渦とともに移動する坐標系から みたものであり，このとき，以下のことが結論される. すなわち，

（ア）海岸線近傍に位置する孤立した渦は，海岸線か らイメージ効果を受けて海岸線に沿って自走する.

（イ）海岸線に立って観測するとき，右旋の渦は左方 へ，左旋の渦は右方へと自走する.

（ウ）渦の自走速度は，2．の式（1）によって計算 される.ここに $a$ は渦軸の海岸線からの距離である。

（エ）渦の自走にはただ単なる渦運動という運動形態 の位相のみならず，実質水塊の輸送が伴う.

（才）実質水塊輸送のキャリヤは渦コアおよび周囲水 塊によって構成され，海岸線に沿って $3.5 a$, 沖合いに 向かって, $2 a$ の範囲に及ぶ。

（カ）渦コアの輸送は Helmholtzの渦定理によって 説明できるが, 周囲の水塊の輸送はイメージ効果そのも のに起因する.

（キ）海岸線に沿って沿岸流が発生する．その最大流 速は自走速度の約 4 倍である.

以上のように, 渦対モデルは最も簡略化されたもので あるにもかかわらず，イメージ効果に起因する自走渦の 特性本質をよく表現している.

われわれの対象としている海岸線近傍の渦をさらによ く表現する「渦輪モデル」をFig.13に示す.いま, 図 (b) のように海底が水際線より沖合に向かって一様に傾斜し ているものと想定する，渦軸は海面と海底とに直交する からその最も簡単な場合として, 渦軸を水際線を中心と する円弧とみなすものとする。このとき，この有界な渦 のまわりの流れは図 (b) に示す無限の完全流体中の渦 輪の場をそれを横切る運動のないような 2 つの平面 $\alpha$, $\beta$ によって切り出したものと同等になることが先の渦対

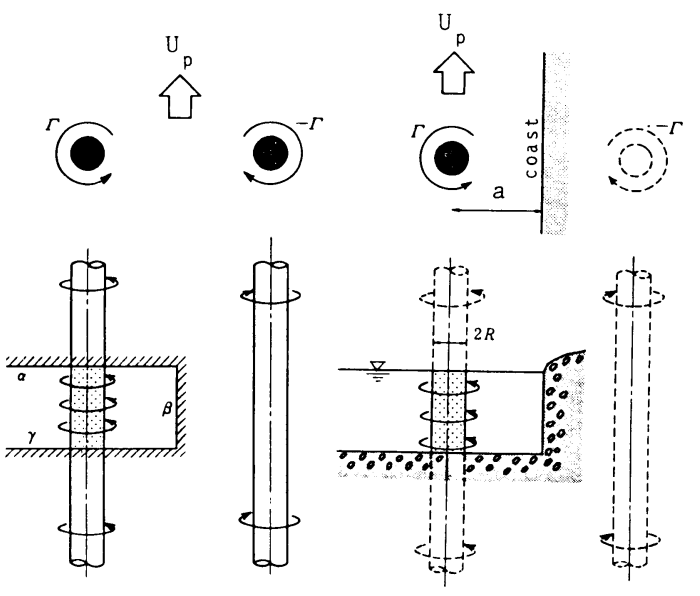

(a)

(b)

Fig. 11 Vortex-pair model ; ( (a) vortex-pair, (b) image effect of the coast)

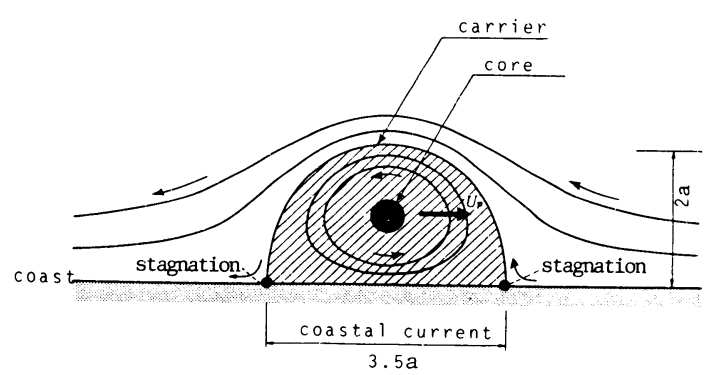

Fig. 12 Streamlines of a self-propelled marine vortex; based on the vortex-pair model.
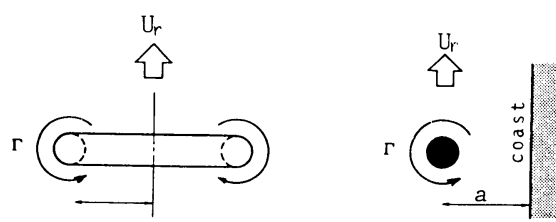

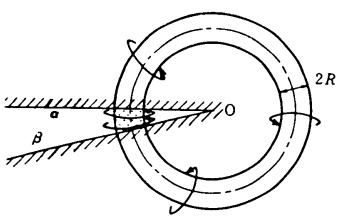

(a)

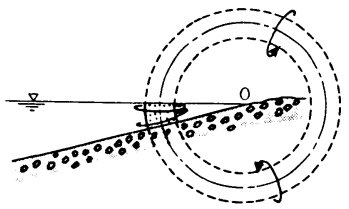

(b)
Fig. 13 Vortex-ring model; ( (a) vortex-ring, (b) image effect of the coast)

モデルの場合の延長として期待できる，渦輪の運動もま た，渦運動論に詳しい記述があり，それをそのまま沿岸 海域の自走渦に適用することができる.

渦輪モデルによって得られる自走渦の性質は渦対モデ ルによって得られるものと基本的には同じであるが, 自 


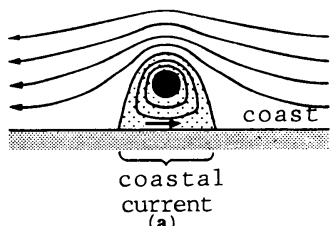

(a)

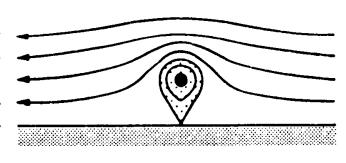

(b)

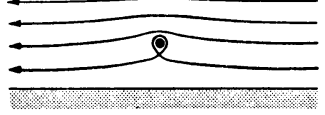

(c)

Fig. 14 Streamlines of a self-propelled marine vortex; based on the vortex-ring model.

走速度および実質水塊輸送の形態が異なる。すなわち, 自走速度は，

$$
U_{r}=\frac{\Gamma}{4 \pi a} \log \frac{6 a}{R}
$$

と表わされ自走速度がコアの半径 $R$ の関数である.

Fig. 14 に渦之行動を共にする移動座標系からみた定常 流線網を示す．図中，(a) においてはコア径が大きく自 走速度は小さいものの水塊輸送のキャリヤは海岸線に達 し，沿岸流をみることができる。一方，(c) においては コア径が小さく自走速度は大きいもののキャリヤは渦コ ア近傍に限られ，沿岸流は生じない，両者の中間に位置 する (b) に対応する $R / a$ は約 $1 / 100$ である.

\section{（2）渦輪モデルの実験的検証}

以上の運動論的モデルにおいては, 有界な渦周りの運 動に無限に続く渦の運動論を適用しようとするためにい くつかの仮定を設けている．そこで，これらの仮定の妥 当性を裏付ける目的でややスケールの大きい水理模型実 験を行う. 実験装置および方法の概要を Fig. 15 に示す. $20 \mathrm{~m} \times 30 \mathrm{~m}$ の平面水槽内に一様勾配 $1 / 20$ の海底地形模 型を設置した，自走渦の発生は鉛直側壁に接して置かれ た幅 $1.8 \mathrm{~m}$ の渦発生板によって行われた。この渦発生 板はまず $\beta$ 氏によって所要の強さとコア径をもつ渦が 形成されるまで海岸線に向かって引き寄せられたうえで $\alpha$ 氏によって水面上に引き上げられる．この操作によっ て生じる左旋の渦の直径は $1 \sim 3 \mathrm{~m}$, 海岸線からの距離 は約 $6 \mathrm{~m}$ ，背丈は約 $30 \mathrm{~cm}$ ，アスペクト比は約 $1 / 10, R$ / $a$ は 1 のオーダーである.これらの幾何学的諸元は沿

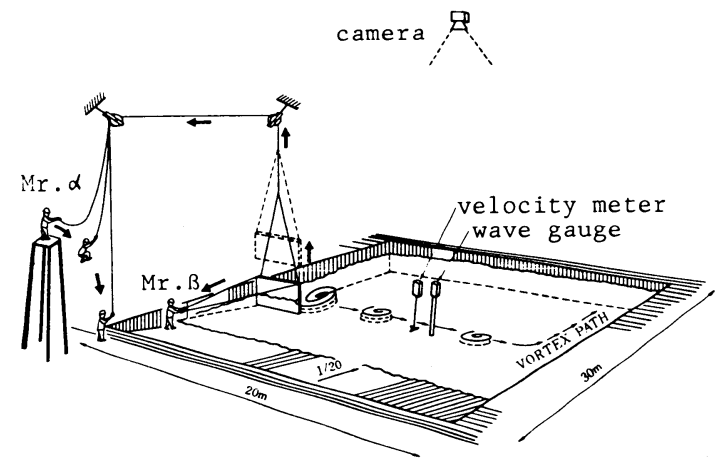

Fig. 15 Apparatus and methods.
岸海域の原型の自走渦とほぼ相似である。一方, 運動学 的相似は無次元時間をも原型と等しくとることを要求す る.この場合，時間の代表スケールが前もって決まらな いために運動学的相似もまた同時に成り立つ。

流れおよび実質水塊輸送状況の目視観測を目的として 渦コアと周囲流体とが微小の浮子によって可視化され， 水面比方のカメラによる連続写真撮影が行われた。自走 速度 $U_{0}$ および渦軸の海岸線からの距離 $a$ は実測され た。

測定の精度向上のために 2 種類のセンサーによる水理 量の直接測定がなされた。渦内部の流速分有測定を目的 として渦軸の自走路上にプロペラ流速計を固定した．自 走路上の流速は海岸線に平行な自走成分とそれに垂直な 渦の回転成分との和である。ここでは流速計出力が回転 成分のみを表わすようにプロペラ回転軸を海岸線に垂直 に固定した。渦内部の静水圧分布か同じく渦軸の自走路 上に固定した水位計によって測定された．渦内部の鉛直 流速成分を微小と仮定すると水位計からの出力は渦内部

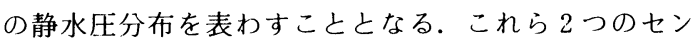
サーからの時系列出力はペンレコーダによって 1 枚の記 録紙上に記録された。

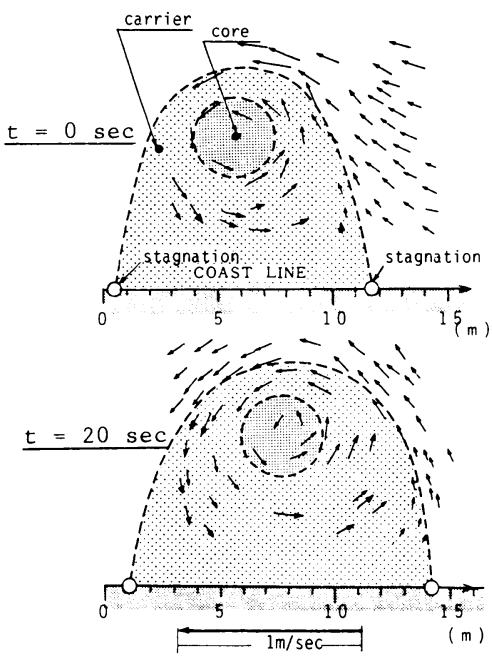

Fig. 16 Photo data of velocity distribution and of substantial mass transport. 
実験は計 17 ケース行われた. 連続写真上に同一パター ンのトレーサの移動を追跡していくことによって Fig. 16 に示すような一連のべクトル図が描かれた。図 中, コアの位置変化は絶対座標によって示してあり, 流 速ベクトルは自走速度の実測值 $U_{0}$ をもて移動する座 標系からみたものである.また,図上には写真判読によっ て剛体回転と認められる渦コアを示している。これらの ベクトル図および写真判読をもとにコア径およびコア外 縁の流速の第 1 の実験值である $R_{1}, u_{1}$ が求められた.

流速計および水位計からの時系列出力の一例を Fig. 17 に示す. 図中（a）は回転流速の分布を示し, 零 流速の点はこの時点において渦軸が流速計設置点を通過 したことを意味する. 渦コアの外縁は最大流速の点 $\alpha$, $\beta$ として表わされ, 両者間の直線状の流速分布はこの部 分が㓮体回転をなすことを意味する．この流速分布から コア径およびコア外縁流速の第 2 の実験值 $R_{2}, u_{2}$ が次 のように求められる.すなわち,

$$
R_{2}=\frac{1}{2} U_{0} \cdot \Delta t, \quad u_{2}=\frac{1}{2}\left(u_{\alpha}-u_{\beta}\right)
$$

ここに， $U_{0}$ は自走速度の実測値， $\Delta t$ は 2 点 $\alpha, \beta$ 間の 時間差， $u_{\alpha}, u_{\beta}$ は $\alpha, \beta$ 点における流速である.一方, 図中 (b) の水位計出力においては, 最大凹み $\Delta h$ の点
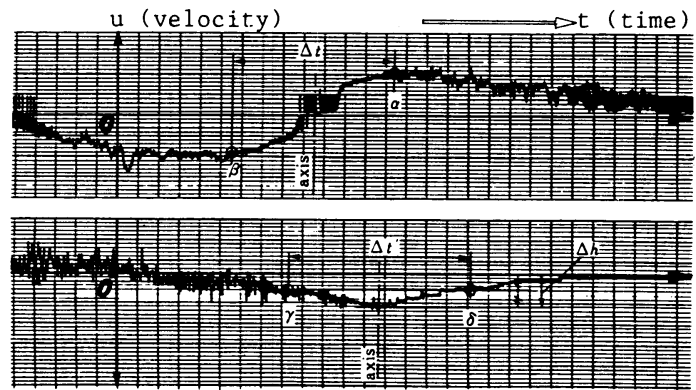

h (surface depression)

Fig. 17 Outputs from velocity meter and from wave gauge.
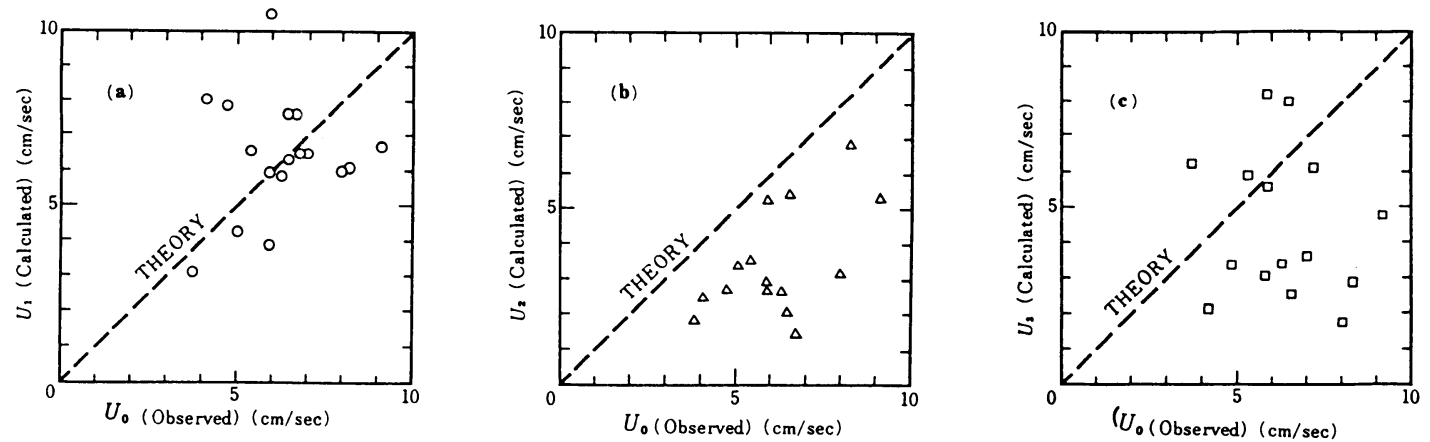

Fig. 18 Comparison of the calculated self-propelled speed with the observation; ( (a) : calculated from photo data, (b) : from velocity data, (c) : from pressure data)
がこの時点における渦軸の水位計通過を意味する.いま, 2 点 $\gamma, \delta$ を凹み $\Delta h / 2$ の点とすれば, ランキン渦近似 を適用することによってコア径およびコア外縁流速の第 3 の㬰測值が次のように求められる.すなわち,

$$
R_{3}=\frac{1}{2} U_{0} \cdot \Delta t^{\prime}, \quad u_{3}=\sqrt{g \cdot \Delta h}
$$

ここに, $\Delta t^{\prime}$ は 2 点 $\gamma, \delta$ 間の時間差である。

以上のコア径およびコア外縁流速の 3 種類の実測值か ら, 自走速度の 3 種類の計算値が渦輪モデルによって計 算された。すなわち,

$$
U_{i}=\frac{\Gamma_{i}}{4 \pi a} \log \frac{6 a}{R_{i}}=\frac{R_{i} u_{i}}{2 a} \log \frac{6 a}{R_{i}}
$$

ここに， $a$ は渦軸の海岸線からの距離の実測値である.

これらのおのおのの計算値と実測値との比較を Fig. 18 に示す，横軸は実測値，縦軸は計算值である，図中の破 線にプロットが乗るとき，そのデータは渦輪モデルをよ く裏付けているといえる. ベクトル図からの計算值 $U_{1}$ は実測値 $U_{0}$ とおおむね対応しているが，流速分布から の計算値 $U_{2}$ および静水圧分布からの計算値 $U_{3}$ は実測 值よりもやや低い評価を与える．この傾向はセンサーを 正確に渦軸の自走路上に設定することが困難であったと いう実験上の制約に起因する.

トレーサの移動の目視観測によれば，これらの自走渦 においてはキャリヤ外縁からの流線の剔離が生じること なく，渦の自走および実質水塊輸送がきわめて効率よく 転として観察される部分であり，キャリヤの外縁は海岸 線に目視観測された 2 個のよどみ点を結ぶ 1 本の流線で ある．本実験における $R / a$ は少なくとも $1 / 10$ であり， ほとんどがこの長円形のキャリヤを示した。以上の実験 的事実は，水塊が自走渦という運動形態をとることに よってダランベールの背理を回避していることを示すも のである. 遂行された。Fig.16中のコアは，連続写真上に用体回 


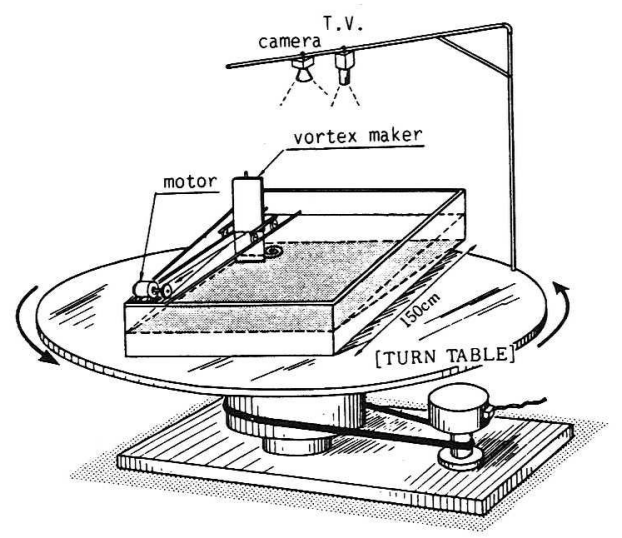

Fig. 19 Apparatus and methods.

\section{（3）地球自転の影響の実験的評価}

対象とする海洋流動の時間スケールが数日のオーダー に及ぶようになると, 地球自転の影響を考慮する必要が 生ずる. 地球自転は本来は運動論的な要素であるにもか かわらず従来の海洋流動研究においてはコリオリ力とい う仮想の力として考慮されるのが通常である.しかしな がらここで解析の道具として用いている渦運動論にお いては地球の自転は考慮されていないので第 2 の実験を 行ってその影響を評価した.

Fig. 19 に実験装置および方法を示す. 直径 $2 \mathrm{~m}$ の ターンテーブル上の $1.5 \mathrm{~m}$ 平方の水槽内において水平 海底面および $1 / 20$ 勾配海底面について実験を行った。 渦の発生方法は前実験と同様であるが渦発生板の駆動は モーターを用いる. 実際海域の自走渦との間の幾何学的 相似はアスペクト比および $R / a$ によって評価された. これらの值はおのおの 0.1 および 1 である. 一方, 運動
学的相似は無次元時間 $T^{*}$ によって評価された.すなわ 5,

$$
T^{*}=\frac{T_{v}}{T_{e}}
$$

ここに, $T_{v}$ は渦の自転周期, $T_{e}$ は地球の自転周期であ る. 本実験においては黒潮によって生ずる自走渦を想定 して $T^{*}$ を 0.1 に設定した.なお, 実験の際の地球自転 は北半球を想定し，回転周期を 90 秒としている. 実験 は水平および $1 / 20$ 勾配の海底地形のおのおのに対し， (A) 地球自転なしの条件下における左旋の渦，(B) 地 球自転下の左旋の渦，および (C) 地球自転下の右旋の 渦の 3 ケースを想定した．渦の形成時に染料によってコ アを可視化し，ターンテーブルに固定したカメラによつ て連続撮影した。水平海底面に対する夷験結果の一例を Fig. 20 に示す. 各実験ケースにおける渦の挙動の概略 は以下のとおりとなる.

(A)：地球自転なしの左旋の渦は形成終了後, 海岸線 に沿って自走する. 自走速度の実測值は連続写真から求 めた渦の強さと海岸線からの距離とをもとに渦対モデル によって評価された計算值によく一致した.

(B)：地球自転下の左旋の渦は同様に式（1）の自走 速度で海岸線に沿って右方へと移動すると同時に海岸線 へと接近する運動を呈する. 特に着目すべきは (A) と 比較して渦運動がより長い時間安定して続くということ である。

(C) : 地球自転下の右旋の渦は海岸線に沿って左方へ と自走すると同時に沖合へと押し出され, 渦の自走, 渦 自体の安定性の双方が損なわれる.

以上のように地球自転は左旋の渦の自走機構およびそ の存在の持続性を強化するが, 一方, 右旋の渦のそれら

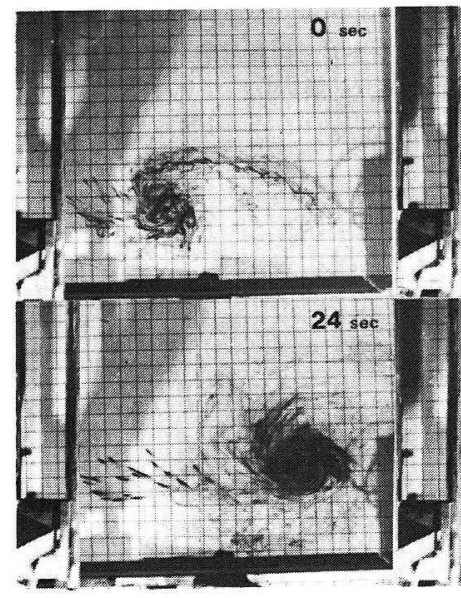

(A) counterclockwise vortex \& no earth rotation

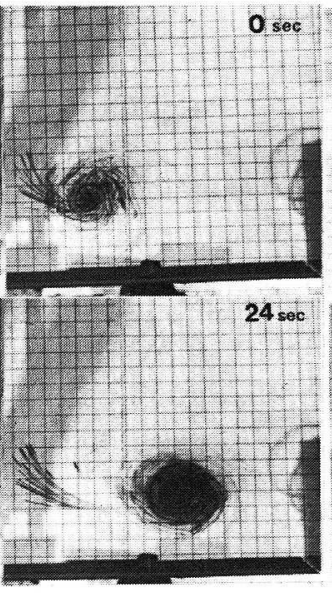

(B) counterclockwise vortex \& earth rotation

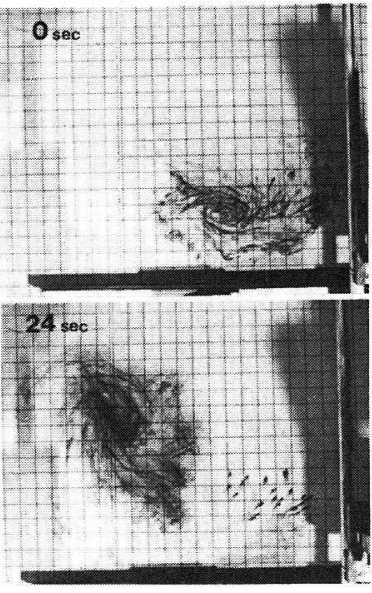

(C) clockwise vortex \& earth rotation

Fig. 20 Experimental results. 
を弱化する作用をもつということができる.

一様勾配海底地形条件下における実験結果もまた，基 本的には上と同様である。ただし，自走速度としては渦 輪モデルに基づく式（2）が適用される。一様勾配の効 果は, 左旋の洬の安定化と海岸線への接近および右旋の 渦の不安定化と沖合への離脱の傾向を助長するように働 く.これは, 地球自転と水深変化との複合による相対渦 度の生成に起因するものと思われる。これらの結果はわ が国太平洋岸に黒潮との間のシアーによって形成される 左旋の渦の安定性に地球自転が大きい役割を果たしてい ることを示すものである。

\section{5. むす び}

本論文は, 黒潮あるいは潮流と海岸線との間のシアー によって形成される自走渦に対してリモートセンシング データに立脚した運動論的解析を施したものである。ま ず，沿岸海域の渦の自走というマクロスケールの水塊移 動がリモートセンシング技術の導入によ一て有効に観測 されることを，駿河湾および明石海峡における観測例に よって示した。次に，海岸線に沿う自走渦について渦運 動論的な解析を施し, 渦の自走, 渦に伴う実質水塊輸送, 沿岸流などの発生メカニズムを明らかにした。これらの 解析結果は水理奏験によって検証され，また，黒潮に伴っ てわが国太平洋岸に発生する左旋の渦の自走機構が地球

自転によって促進されることは実験的に示された。

水理実験に際して，木ノ瀬紘一博士 (農業土木試験場) には多大なご協うを賜った。 Fig. 6 の NOAA 画像は, 杉村俊郎氏（リモートセンシング技術センター）の提供 による，明石海峡の流況については，藤原建紀氏（中国 工.業技術試験所）のご教示を得た。深甚の謝意を表する. 本研究は文部省科学研究費（No. 56550356）を受けて 奏施された。

\section{参 考 文 献}

1) Maruyasu, T., Onishi, S. and Nishimura, T. : Study of tidal vortices at the Naruto Strait through remote sensing, Bull. of the Remote Sensing Labo., Remote Sensing Series No.1, Science University of Tokyo, 1981

2) Robinson, Allan R. : Eddies in Marine Science, Sprin ger-Verlag Berlin Heidelberg New York Tokyo, 1983.

3) Lamb, H. : Hydrodynamics, 6th ed., Cambridge University Press, pp. 202 249, 1975.

4) Barker, S. J. and Crow, S. C. : The motion of two dimensional vortex pairs in a ground effect, Journai of Fluid Mechanics, Vol. 82, part 4, pp. 659 671, 1977.

5) Hatakeyama, Y., Tanaka, S. and Nishimura, T. : A formation process of an oceanic vortex analyzed by multi-temporal remote sensing, Proceedings of the 15 th ERIM, pp. 1173 1185, 1981.

6) 中村保昭 -千葉 位: 伊豆諸島北部周辺海域における海 況の短期変動, 静岡水産試験場報告第 15 号, pp. 1 $7,1981$.

7）杉村俊郎・田中総太郎・畠山祐二：1983 年春の日本周辺 海域の流動, 1983 年度日本海洋学会秋季大会講演要旨集, pp. $25 \sim 26,1983$.

8) 田中総太郎・杉村俊郎・西村司・二宮泰・香山祐二 : NOAA-6/AVHRR デー夕による黑潮流動ベクトル図の 作成と海洋渦および短周期蛇行に関する考察, 日本りモ一 トセンシング学会誌, Vol.2, No. 3, pp. 11 30,1982.

9）杉村俊郎・田中総太郎・舅山祐二- 西村 司：1983 年秋 の日本周辺海域の流動, 1984 年度日本海洋学会春期大会 講演要旨集, pp. $282 \sim 283,1984$.

10）海上保安厅：潮汐表第一巻日本及び付近.

11）中国工業技術協会：現地資料から見た明石海陕付近の海 水流動, 明石海陕にお打る流跡の形究報告書別冊, p. 85,1977 .

12）藤原建紀：海水交換（1），大阪湾にトラップされた播磨 灘系水, 1979 年度日本海洋学会秋期大会講演要旨集, pp. 12 13, 1979 .

13）L.プラントル (白倉昌明・橘藤雄監訳)：流れ学 (上), コロナ社, p. 84, 1972 .

(1983.5.31 • 受付 